\title{
SHOEMAKER COACHING IN CAMPAKAMULYA VILLAGE (SME PARTNER: SOPIAN)
}

\author{
Sambudi Hamali $^{1 *}$, Teddy Indira Budiwan ${ }^{1}$, Taufik ${ }^{1}$ \\ ${ }^{1}$ Bina Nusantara University \\ *sambudi_hamali@binus.ac.id
}

\begin{abstract}
Sopian, a shoemaker, is one of several shoemakers in Campakamulya village, Cimaung District, Bandung Regency. The usual problem found is lack of funding to expand the business and difficulties in marketing the products. The purpose of this activity is to give the knowledge, training, and coaching on SWOT analysis (Strengths-Weaknesses-Opportunities-Threats) and marketing strategies. The target of this community service is expected to give the best understanding and plan for future business development and getting funding by reorganizing and expanding the marketplace. The result shown is Sopian's increasing knowledge of SWOT analysis and marketing strategy, sales increased and increased assets that have a gallery.
\end{abstract}

Keywords: Marketing strategy, shoemakers, SWOT

\section{INTRODUCTION}

The shoe business is a promising business, being that shoes are one of the human basic necessities. Man needs his shoes for activities, such as going to school, going to work, doing sports etc. In other words, the needs for shoes are as basic as for the need for food. A large market for shoes makes shoe home industry always open for the possibility of profit and a good future. The market share is not only nationwide but can also be exported to foreign countries (Investasi Untung, 2017). In addition, a growing trend in recent years has made people appear bolder in fashion. In ancient times people may be satisfied with having shoes or slippers with standard colors such as black or brown. However, nowadays, the colors used are more diverse, such as blue, green, red and others. This rapid change in shoe trends has led to many craftsmen or shoe entrepreneurs trying their luck in the business. This courage is not only triggered by trends alone, but also the increasing appreciation from the public for local products. As a result, more and more businessmen are bringing forward their own brand (Kontan, 2014).

Sopian is one of the businessmen trying their luck in the leather shoes. Sopian started his leather shoe business in 2015, continuing a lapsed heritage business. His workshop is located in Desa Campakamulya, Kecamatan Cimaung Kabupaten Bandung. The location was chosen considering that it would open up jobs to the surrounding neighborhood and that he wouldn't have to rent for a workshop being the property is his own. In the beginning, Sopian focused on producing shoes for the military. Some agencies that ordered shoes from the Sopian are Arhanud, Armed, Kaveleri, Batalyon 4 tanks, Military Police, Traffic Police, Brigif, Kodam, and Kodim. Some of the unique products are military shoes with a more trendy design, as shown in the picture below: 

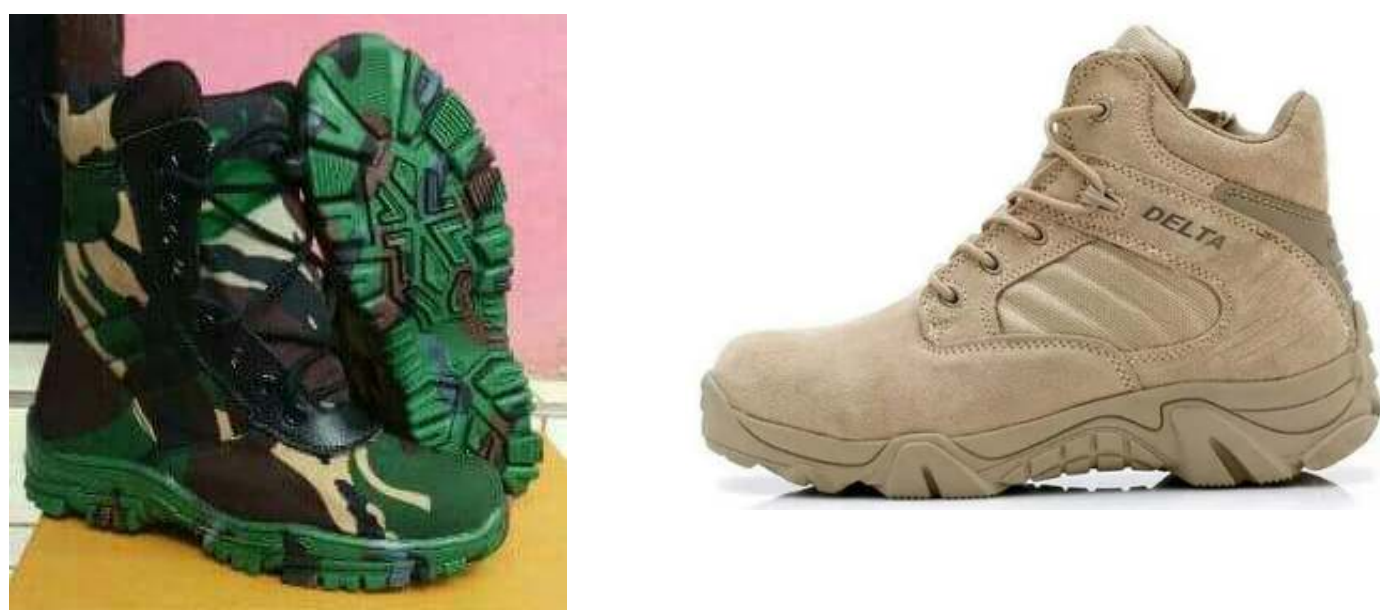

Figure 1. Sopian leather shoe product

The lack of capital and promotional tools are two of the main problems faced by this particular leather shoe craftsman. The lack of venture capital rendered Sopian to unable to develop and expand his business. Therefore he is only dependent on his consumers' orders. The promotional tools are also a major problem. Based on interview and observation, it was found that the promotional tool used was the only word of mouth of his consumers and personal Facebook. There was no catalogs, only product pictures made so that there is only limited potential buyer targeted and interested to buy his product.

Based on the previous description, in order to win the competition, shoe players must conduct several things: they have to know their strength, weakness, opportunity, and thread in their shoe industry; they have to conduct promotion strategy, using more traditional tools as well as the more modern ones. One of the tools to know strength, weakness, opportunity, and the threat is the SWOT tools (Strengths, Weaknesses, Opportunities, Threats).

SWOT analysis is a tool commonly used during the audit process (Drummond, et al, 2008). This tool is to be used to filter out critical factors that have been identified during the auditing process. Organizational strengths and weaknesses must be assessed in relation to the opportunities and threats identified in the external environment. The purpose of the SWOT is to highlight important issues to focus during the development of the strategy. The matrix of Strengths-Weaknesses-OpportunitiesThreats (SWOT) is an important matching tool that helps managers develop four types of strategies: SO Strategy, WO Strategy, ST Strategy and WT Strategy (David \& David, 2017).

Therefore, the solution offered to this leather shoe craftsman is to first provide knowledge in the form of training on analysis of strengths, weaknesses, opportunities, and threats in the leather shoe business using SWOT analysis. With SWOT analysis, it is expected to encourage these craftsman to find a variety of policy ideas that are more fresh and fresh, and more effective and make improvements to the organization, so that financial institutions are expected to help add business capital. At a later stage, after the grant of the knowledge of the SWOT analysis, the next step was conducting a training and mentoring on marketing strategies, including through online sale, with the expectation of having more people being aware of products from Campakamulya and for the business to be able to overcome the problems encountered, such as marketing.

The purpose of this activity is to provide knowledge and training on SWOT analysis and marketing strategies. The expected service for Sopian's shoe business is to provide the best understanding and plan for future business development and to get funding from financial institutions by reorganizing and expanding the market so that the difficulties faced such as lack of capital and marketing the products can be overcome. 


\section{Theoretical Framework}

One of the most popular approach to collect and analyze marketing information is situational analysis. The purposes of situational analysis are to describe the current and future issues, and main trends, because these three things influence three key environments namely internal environment, customer environment and external environment (Ferrell \& Hartline, 2014), Next, how can marketing manager manage and use information collected during situational analysis? One of the tools that are widely used is the SWOT analysis (Strengths-Weaknesses-Opportunities-Threats). SWOT analysis consists of the company internal and external environment. Many consider a SWOT analysis as one of the most effective tools in the analysis of marketing data and information. SWOT analysis is a simple and straightforward framework that provides direction and serves as a catalyst for the development of a viable marketing plan (Ferrell \& Hartline, 2014).

SWOT analysis is designed to achieve two main objectives (Wilson \& Gilligan, 2005):

1. To separate the meaningful data from the only interesting one.

2. To know what management must do to better exploit its distinct competencies in both the current market and the future.

According to Hooley, Piercy, Nicoulaud \& Rudd (2017), there are two purposes of SWOT, First, to try to identify the most significant factors, both internally and externally, that influence the organization and the market. Second, by visualizing both strength and weaknesses in par with opportunity and threat, the company can have an aid in formalizing a strategy.

As a means of planning, SWOT analysis has many benefits (Ferrell \& Hartline, 2014), among them:

1. Simplicity

SWOT analysis does not require extensive training or technical expertise to be used successfully. The analysis only requires a comprehensive understanding of the nature of the company and the industry he's competing in.

2. Lower Costs

Because special training and expertise are not required, the use of SWOT analysis can really reduce the cost related to strategic planning

3. Flexibility

SWOT analysis can increase the quality of organizational strategic planning even without an extensive marketing information system.

4. Integration and Synthesis

SWOT analysis can provide the analyst with the ability to integrate and synthesize some information, either quantitatively or qualitatively. The SWOT analysis can handle many kinds of information. SWOT analysis can even help to change the diversity of information of a weakness in planning to be its strength.

5. Collaboration

SWOT analysis induces collaboration and open information exchange between different kinds of functional division.

SWOT analysis is a part of the organizational strategic planning stage that consists of three stages: data collection stage, analysis stage, and decision-making stage. During the data collection stage, there are two matrices of data collection: Internal Factor Evaluation (IFE) Matrix and External Factor Evaluation (IFE) Matrix. After collecting all the relevant information for the sustainability of the company, the next stage is the analysis stage. This uses the information from the previous stage into a quantitative model for strategy formulation, one of which is the Internal-External (IE) Matrix. To construct the strategy to be done by connecting the internal factors as far as the strength owned can catch the opportunity and neutralize the challenge and threat, as well as turning a weakness into a competitive advantage. After knowing the strategy to do, the last stage is decision making.

An important requirement for a success of a company is that the solution provided is felt by the consumer and is perceived to be beneficial. Communication as a marketing instrument must be defined better in terms of target. Marketing communication thus includes elements of the marketing mix that foster the relationship between the organization with its customers through the exchange of information, 
ideas, opinions, etc., often interpreted as a means of influencing customer behavior in the market. Two classical instruments of marketing communications are advertising and sales promotion (Tomczak, Reinecke \& Kuss, 2018).

\section{METHOD}

Method of implementation of the activities of community partnerships is in the form of training on the analysis of strengths, weaknesses, opportunities, and threats in the leather shoe business. With the SWOT analysis is expected that the businessman will be able to choose the best policy and plans for the development of business in the future. By knowing the weakness and opportunity as well as the strength and the threat from the external, they will find a more fresh idea, will be more effective in becoming more effective in the issues dealt with, such as capital and marketing.

Asides from SWOT analysis, control and evaluation were also conducted to ensure the effectiveness of the SWOT analysis toward the organization management. It is hoped that with the organization revamps based on SWOT analysis, financial institutions can start helping with capital and also an increasing market size for the shoe business. The next stage is the training and coaching on marketing strategy, some of which is through online sales, such as Tokopedia or Bukalapak so that it is hoped that the brand and product awareness of the leather shoe businessman can increase, making more people aware of the product from Campakamulya as well as bringing an end to the problem of marketing the product.

By conducting the training to the SME partner on SWOT analysis and marketing strategy, the knowledge on organizational management can be used again in the future if need be, and he can control and evaluate on his own.

Data collection technique was using interview and observation. The activity conducted from March to August 2018.

\section{RESULT AND DISCUSSION}

On the first coaching session in April 2018, the material intended was on SWOT analysis and training on SWOT analysis. At the end of the first coaching session, a brainstorm was conducted to gain the strength, weakness, opportunity, and threat of the leather shoes, specifically Sopian's business. From the brainstorming, it was gathered that Sopian has the interest to build a gallery and a workshop for his business. At the end of the coaching session, the researchers gave Sopian a task to calculate the weight of each of the SWOT element, from which the data will be gathered again in the next coaching session. After the training and mentoring of the SWOT analysis, the second phase was again carried out in August 2018. During the second visit, Mr. Sopian had set up a showroom and workshop as a result of the brainstorming during the first phase visit. Where the construction of showrooms and workshops has reached $90 \%$. In the second phase of the mentoring, together with Sopian, we conducted a SWOT analysis of the shoe business as a continuation of the task we gave in the first phase. Based on the calculation conducted, the value of IFE (Internal Factor Evaluation) was 3.05 while the EFE (External Factor Evaluation) was 3.30. 
Table 1. The Results of the SWOT Analysis of Internal Factors of Sopian's Business.

\begin{tabular}{|c|c|c|c|c|}
\hline \multicolumn{5}{|c|}{ INTERNAL } \\
\hline Strength (S) & Weight & Rating & $\begin{array}{l}\text { Weight } \\
\text { x } \\
\text { Rating }\end{array}$ & Comments \\
\hline 1. Labor & 0,10 & 3 & 0,3 & $\begin{array}{l}\text { Have a high motivation and loyalty in } \\
\text { finishing all job. }\end{array}$ \\
\hline 2 The workshop itself & 0,15 & 2 & 0,3 & $\begin{array}{l}\text { To have own's workshop to ease the } \\
\text { fulfillment of products order as per } \\
\text { standard }\end{array}$ \\
\hline $\begin{array}{l}3 \text { The relationship between } \\
\text { owner and employees }\end{array}$ & 0,10 & 3 & 0,3 & $\begin{array}{l}\text { A good relationship that any products } \\
\text { produced were up to specs }\end{array}$ \\
\hline $\begin{array}{l}\text { 4. A good relationship with } \\
\text { raw material suppliers }\end{array}$ & 0,10 & 3 & 0,3 & $\begin{array}{l}\text { A good relationship with suppliers to } \\
\text { ensure a constant supply of raw material }\end{array}$ \\
\hline $\begin{array}{l}\text { 5. Connection with } \\
\text { marketing distribution }\end{array}$ & 0,10 & 4 & 0,4 & $\begin{array}{l}\text { A good relationship so that products are } \\
\text { easy to sell }\end{array}$ \\
\hline Weaknesses (W) & Weight & Rating & $\begin{array}{l}\text { Weight } \\
\text { x } \\
\text { Rating }\end{array}$ & Comments \\
\hline 1. Showroom & 0,10 & 3 & 0,3 & $\begin{array}{l}\text { Do not have a showroom, so visitors do } \\
\text { not see the results of the product as a } \\
\text { whole }\end{array}$ \\
\hline 2. Location & 0,15 & 3 & 0,45 & $\begin{array}{l}\text { Access to the location still has no sign } \\
\text { and there is no parking space }\end{array}$ \\
\hline 3. Marketing channel & 0,10 & 3 & 0,3 & $\begin{array}{l}\text { Marketing channel is not large enough } \\
\text { and is still focused on the army/police }\end{array}$ \\
\hline 4 Product innovation & 0,10 & 4 & 0,4 & $\begin{array}{l}\text { Lack of innovation in product to create } \\
\text { updated products. }\end{array}$ \\
\hline $\begin{array}{l}\text { Total of Weight value, } \\
\text { Weight x Rating }\end{array}$ & 1,00 & & 3.05 & \\
\hline
\end{tabular}

Source: Data processed, 2018 
Table 2. The Results of the SWOT Analysis of External Factors of Sopian's Business

\begin{tabular}{|c|c|c|c|c|}
\hline \multicolumn{5}{|c|}{ EXTERNAL } \\
\hline Opportunity & Weight & Rating & $\begin{array}{l}\text { Weight } x \\
\text { Rating }\end{array}$ & Comments \\
\hline 1. Marketing to retail & 0,20 & 3 & 0,5 & Opportunity in retail (B2C) \\
\hline $\begin{array}{l}\text { 2. Support from the local } \\
\text { government for a tour village. }\end{array}$ & 0,20 & 3 & 0,6 & $\begin{array}{l}\text { With Puntang officially named a } \\
\text { tour village, there will be tourists } \\
\text { coming as market potential. }\end{array}$ \\
\hline $\begin{array}{l}\text { 3. Consumer's demand for } \\
\text { innovative products. }\end{array}$ & 0,10 & 4 & 0,4 & $\begin{array}{l}\text { There is a need for products that are } \\
\text { regularly updated. }\end{array}$ \\
\hline Threats (T) & Weight & Rating & $\begin{array}{l}\text { Weight } x \\
\text { Rating }\end{array}$ & Comments \\
\hline $\begin{array}{l}\text { 1. Some villages around the } \\
\text { location }\end{array}$ & 0,20 & 3 & 0,6 & $\begin{array}{l}\text { There are some tour village around } \\
\text { Bandung }\end{array}$ \\
\hline 2. Similar shoe businessman & 0,20 & 4 & 0,8 & $\begin{array}{l}\text { There are similar businessmen in } \\
\text { one kecamatan }\end{array}$ \\
\hline $\begin{array}{l}\text { 3. The progress of information } \\
\text { system }\end{array}$ & 0,10 & 4 & 0,4 & $\begin{array}{l}\text { Have not taken advantage of e- } \\
\text { commerce platform, social media }\end{array}$ \\
\hline $\begin{array}{l}\text { Total of Weight value, Weight } x \\
\text { Rating }\end{array}$ & 1,00 & & 3,3 & \\
\hline
\end{tabular}

Source: Data processed, 2018

Next, strategy analysis was conducted based on the Internal-External (IE) Matrix, where IFE (Internal Factor Evaluation) values were 3.05 and EFE (External Factor Evaluation ) of 3.30.

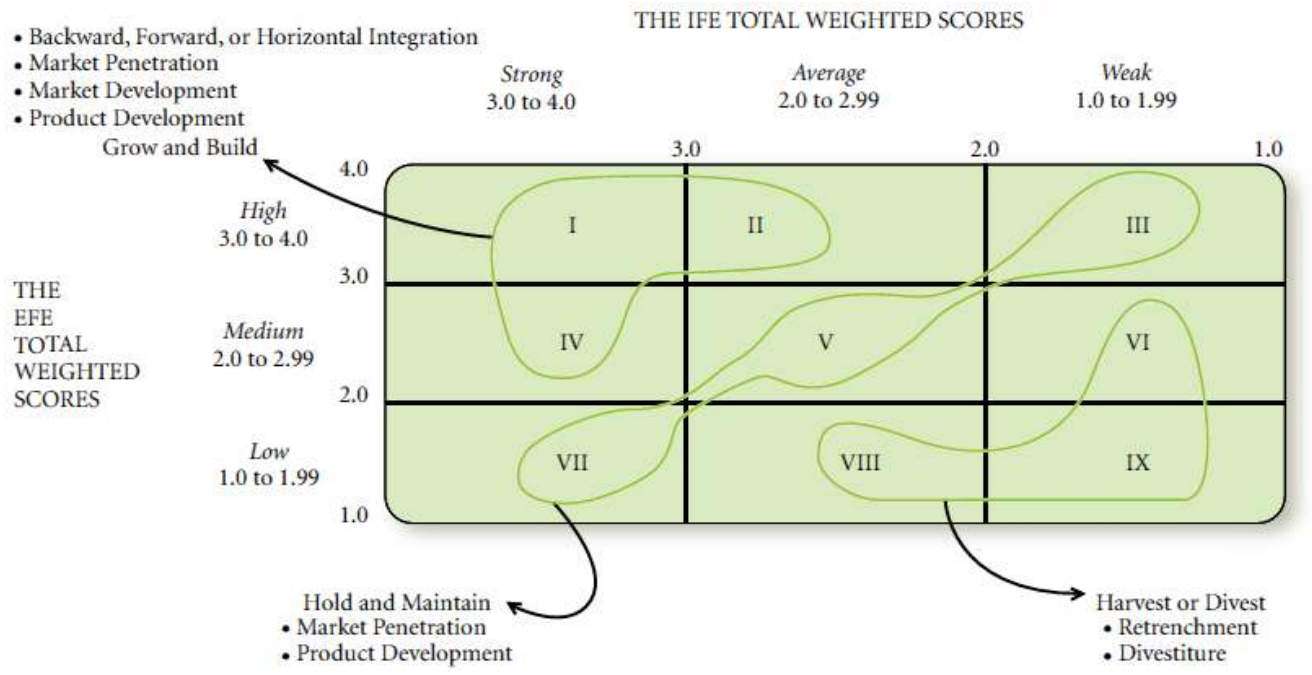

Figure 2. Internal-External Matrix Source: David \& David (2017)

Based on the results, a position on the 1st quadrant, then some of the strategies to be conducted such as Market Penetration, Market Development \& Product Development.

Based on the foregoing, we formulate the future strategy to be conducted with Sopian, such as:

$>$ Impulsive buying: sell with the same theme (shoes), such as key chains, bags, etc.

$>$ B2C: gallery, exhibition \& e-commerce and social media (SEO /Search Engine Optimization paid to advertise) 
Next, we evaluated the outcomes after training and mentoring for 6 months:

Table 3. The results of the Close Community Partnerships Program performance indicators

\begin{tabular}{|l|l|}
\hline \multicolumn{1}{|c|}{ PKM Performance Indicators } & \multicolumn{1}{c|}{ Evidence } \\
\hline Increased Knowledge & $\begin{array}{l}\text { Increased organizational management: SWOT \& } \\
\text { social media marketing strategies }\end{array}$ \\
\hline Skill Improvement & $\begin{array}{l}\text { Increased organizational management: SWOT \& } \\
\text { social media marketing strategies }\end{array}$ \\
\hline Product Quality Improvement & Product fault reduced to 1\% \\
\hline Increase in production capacity & 150 pairs/week to 300 pairs/week \\
\hline Increase in asset & Gallery \\
\hline Increase in revenue & 150 pairs/week to 300 pairs/week \\
\hline Improved management capabilities & $\begin{array}{l}\text { Able to maintain a balance between the increase in the } \\
\text { number of the production to the satisfaction of labour }\end{array}$ \\
\hline Profit increase & 150 pairs/week to 300 pairs/week \\
\hline \multicolumn{2}{|c|}{ Source: Data processed, 2018 } \\
\hline
\end{tabular}

\section{CONCLUSION}

Based on mentoring to Sopian's Business, in the time frame of six-month on the Community Partnership Program, the results obtained that in the first phase of mentoring in April 2018, Sopian had understood about the SWOT analysis and from the results of brainstorming in the first stage Sopian had a desire to build a gallery/workshop for his business. The result of second stage coaching on August 2018, based on the calculation of SWOT for Sopian's business is IFE value of 3,05 and EFE value of 3,30 . Next, a strategic analysis was conducted based on the Internal-External Matrix, where with such value for IFE and EFE, Sopian is in the first Quadrant. Therefore a suitable strategy is Market Penetration, Market Development \& Product Development. Based on the strategy that Sopian has do pursue in the future are Impulsive buying, selling products with a similar theme (shoes), such as keychain, bags, etc., and to sell B2C: gallery, attend exhibitions \& e-commerce and social media(SEO/SEO/Search Engine Optimization paid advertising).

The performance of program performance indicator for the community partnership program with Sopian reveals an increase in organization management skill, a decrease of faulty products to $1 \%$, a gallery, and increase of production from 150 /week to $300 /$ week. 


\section{ACKNOWLEDGMENT}

The authors want to thank Bina Nusantara University. This activity is supported by the community development of Bina Nusantara University in the form grant for Community Partnership Program 2018.

\section{REFERENCES}

David, F. R., \& David, F. R. (2017). Strategic Management: Concepts and Cases. Harlow: Pearson Education Limited.

Drummond, Graeme., Ensor, John., Ashford, Ruth. 2008. Strategic Marketing: Planning and Control. Third edition. Oxford: Butterworth-Heinemann Elsevier.

Ferrell, O. C., \& Hartline, M. (2014). Marketing strategy, text, and cases. Sixth Edition. South Western: Cengage Learning.

Hooley, G., Piercy, N. F., Nicoulaud, B \& Rudd, J. M. (2017). Marketing strategy and competitive positioning. Harlow: Pearson Education Limited.

Investasi Untung. (2017). Rincian Modal Bisnis Sepatu, Keuntungan, dan Cara Memulainya. Retrieved at 3/2/2018 from https://www.investasiuntung.com/2017/03/rincian-modal-bisnis-sepatucara.html.

Kontan. 2014. Usaha sepatu: Biar diinjak, labanya melejit. Retrieved at 3/2/2018 from http://peluangusaha.kontan.co.id/news/usaha-sepatu-biar-diinjak-labanya-melejit

Tomczak, T., Reinecke, S., \& Kuss, A. (2018). Strategic Marketing. Wiesbaden: Springer Gabler.

Wilson, R. M., \& Gilligan, C. (2005). Strategic Marketing Management: Planning, Implementation, and Control. Third Edition. Oxford: Elsevier Butterworth-Heinemann 